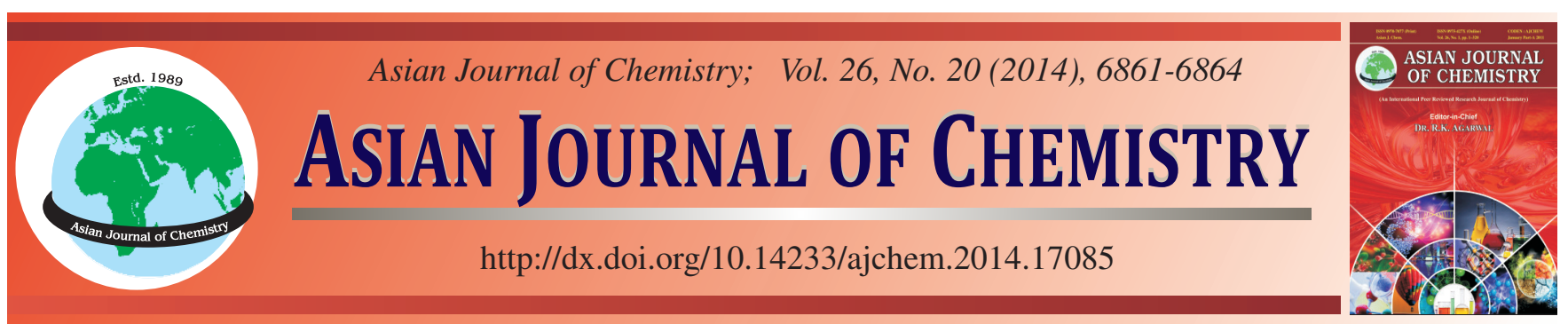

\title{
Dietary Exposure of Adults to Nitrites from Vegetable Intake in Cities Experiencing Immigration from Three Gorges Project in Northeast Chongqing, China
}

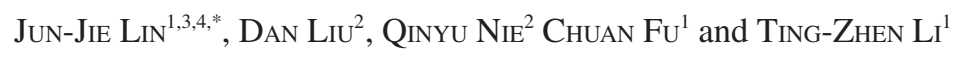

${ }^{1}$ Key Laboratory of Water Environment Evolution and Pollution Control in Three Gorges Reservior, Chongqing Three Georges University, Wanzhou 404100, P.R. China

${ }^{2}$ Department of Agricultural and Forestry Science and Technology, Chongqing Three Gorges Vocation College, Chongqing 404000, P.R. China ${ }^{3}$ State Key Laboratory of Forest and Soil Ecology, Institute of Applied Ecology, Chinese Academy of Sciences, Shenyang 110164, P.R. China ${ }^{4}$ University of Chinese Academy of Sciences, Beijing 100049, P.R. China

*Corresponding author: E-mail: ybu_lin@126.com

Received: 20 January 2014;

Accepted: 25 April 2014;

Published online: 25 September 2014;

AJC-16026

\begin{abstract}
This study examined the intake of vegetable nitrite in cities experiencing migration from the three Gorges project in northeast Chongqing, China. Daily intake was estimated using the Northeast Chongqing population-based vegetable consumption survey 2005-2007 and the nitrite content of various vegetables. The results showed significant variation in average levels of nitrite content among various vegetables. Nitrite levels ranged between $0.12 \mathrm{mg} \mathrm{NO}_{2}^{-} \mathrm{kg}^{-1}$ fresh weight in tomato and $6.14 \mathrm{mg} \mathrm{NO}_{2}^{-} \mathrm{kg}^{-1}$ fresh weight in rorippa. According to the vegetable consumption survey, on an average, residents consume $440 \mathrm{~g}$ of tested vegetables per day. Solanaceous vegetables accounted for $18.23 \%$ of the total vegetables consumed, whereas gourd vegetables, allium vegetables and tuber vegetables accounted for 16.36 , 14.68 and $10.35 \%$, respectively. Other vegetables accounted for less than $10 \%$. Dietary exposure to nitrite from vegetables was estimated to be $0.0066 \mathrm{mg} \mathrm{kg}^{-1}$ body weight day ${ }^{-1}$, which represented $90 \%$ of total vegetable consumption in the study area. Estimated exposure to nitrite was well below the acceptable daily intake of nitrite, at $0.07 \mathrm{mg} \mathrm{kg}^{-1}$ body weight day ${ }^{-1}$.
\end{abstract}

Keywords: Vegetable, Nitrite, Immigrant city, Three gorges project, Dietary exposure, Acceptable daily intake.

\section{INTRODUCTION}

A vegetable-rich diet can make us healthy, high vegetable intake is associated with reduced risk of cardiovascular disease mortality and reduced risk of heart disease ${ }^{1}$, stroke and probably some cancers $^{2-4}$. It also improves vascular function ${ }^{5}$, lowers risk of prostate disease ${ }^{6}$; reduces risk of chronic disease ${ }^{7}$, lowers risk of eye and digestive problems ${ }^{8}$ and has a mellowing effect on blood sugar that can help keep appetite in check ${ }^{9}$.

Humans are exposed to preformed $N$-nitroso compounds (NOCs) and endogenous $N$-nitroso compounds ${ }^{10}$. Most carcinogenic $N$-nitroso compounds (NOCs) are formed by dietary intake of nitrite $\left(\mathrm{NO}_{2}^{-}\right)$and nitrate $\left(\mathrm{NO}_{3}^{-}\right.$, partly converted to nitrite in the body $)^{11,12}$. Nitrite and nitrate are primarily derived from food, but are also used as food additives and preservatives that inhibit bacterial growth and enhance flavor and color ${ }^{13-16}$.

Environmental quality and food safety in the three gorges reservoir areas (TGRA) in northeast Chongqing, China has received considerable attention since June 12, 2003, when the water level reached $135.4 \mathrm{~m}$ and large number of migrants flocked to cities above the water line near the three gorges reservoir ${ }^{17}$. However, serious pollution and food safety problems have arisen with the registered permanent resident population of 2.628 million in TGRA ${ }^{18,19}$.

In the present study, the nitrite $\left(\mathrm{NO}_{2}^{-}\right)$content in vegetables available in markets were analyzed and the dietary intake of nitrite from vegetables was assessed using the method established by the joint FAO/WHO expert committee on food additives $^{20}$.

\section{EXPERIMENTAL}

Sampling and preparation: In total, 840 vegetable samples, including 10 types of vegetables (solanaceous vegetables, gourd vegetables, allium vegetables, tuber vegetables, root vegetables, Chinese cabbage-type vegetables, green leafy vegetables, leguminaceous vegetables, aquatic vegetables and edible fungi) were collected from markets in 11 cities (Wanzhou, Kaixian, Liangping, Yunyang, Fengjie, Wushan, Wuxi, Zhongxian, Dianjiang, Fengdu and Chengkou) in northeast Chongqing during summer (August to September 2012). Each vegetable sample, consisting of 5-10 subsamples, was randomly collected from different markets at each site. All 
samples were cleaned using tap water and the deionized water, then air-dried, minced and homogenized in a tissue homogenizer.

Extraction and analysis: Nitrite concentrations were determined using a standard methodology (ISO 6635:1984 (E)). In brief, a test portion of the vegetable (2-20 g) was extracted with $5 \mathrm{~mL}$ saturated borax solution and $100 \mathrm{~mL}$ hot water $\left(70-80{ }^{\circ} \mathrm{C}\right)$ and proteins were precipitated by addition of $10 \mathrm{~mL}$ potassium hexacyanoferrate (II), $10 \mathrm{~mL}$ zinc acetate and $2 \mathrm{~g}$ activated carbon powder; the precipitate was filtered. Sulfanilamide chloride and N-(1-naphthyl) ethylenediamine were added to the nitrite-containing solutions to allow measurement of the red complex obtained by measuring absorbance at $538 \mathrm{~nm}$. All reagents used in this study were of analytical grade. Deionized water $(18 \mathrm{M} \Omega \mathrm{cm})$ was used for preparing all solutions and for sample extraction.

Estimation of dietary exposure: Dietary exposure to nitrite from various vegetables was estimated using information from the vegetable consumption survey. Average body weight in this population was $60 \mathrm{~kg}$.

\section{RESULTS AND DISCUSSION}

Nitrite in vegetables: To our best of knowledge, this is the first report that compares nitrite levels of vegetables in northeast Chongqing, which is the region that has experienced the largest volume of immigration as a result of the Three Gorges Project. The region covers $33,900 \mathrm{~km}^{2}$, with a registered permanent resident population of 2.628 million and contains
11 cities: Wanzhou, Kaixian, Liangping, Yunyang, Fengjie, Wushan, Wuxi, Zhongxian, Dianjiang, Fengdu and Chengkou. Individual results obtained for nitrite levels are shown in Table-1. Vegetables showed considerable significant variation in average levels of nitrite, ranging from $0.12 \mathrm{mg} \mathrm{kg}^{-1}$ fresh weight in tomato to $6.14 \mathrm{mg} \mathrm{kg}^{-1}$ fresh weight in rorippa. Solanaceous vegetables in decreasing order of nitrite content as follows: sweet pepper $>$ eggplant $>$ hot pepper $>$ tomato. Sweet pepper, with $1 \pm 0.24 \mathrm{mg} \mathrm{kg}^{-1}$ fresh weight, had significantly higher nitrite content than other solanaceous vegetables. Gourd vegetables in decreasing order of nitrite content are as follows: Bitter gourd $>$ cucumber $>$ towel gourd. Bitter gourd, with $2.07 \pm 0.16 \mathrm{mg} \mathrm{kg}^{-1}$ fresh weight, had significantly higher nitrite content than other gourd vegetables. Allium vegetables in decreasing order of nitrite content are as follows: Old ginger $>$ chinese chive $>$ chinese onion $>$ fresh ginger $>$ garlic scape $>$ garlic. Old ginger with $4.93 \pm 0.11 \mathrm{mg} \mathrm{kg}^{-1}$ fresh weight had significantly higher nitrite content than other allium vegetables. Tests of tuber vegetables showed no significant difference between potato and sweet potato in nitrite content. Tests of root vegetables showed that the nitrite content of carrot (1.34 $\pm 0.45 \mathrm{mg} \mathrm{kg}^{-1}$ fresh weight) was significantly higher than that of white radish $\left(0.17 \pm 0.03 \mathrm{mg} \mathrm{kg}^{-1}\right.$ fresh weight $)$.

Vegetables in the Chinese cabbage group in decreasing order of nitrite content are as follows: Cabbage $>$ Chinese cabbage > rape. Cabbage with $1.47 \pm 0.32 \mathrm{mg} \mathrm{kg}^{-1}$ fresh weight had significantly higher nitrite content than other cabbagetype vegetables. In green leafy vegetables, rorippa had the highest nitrite content at $6.14 \mathrm{mg} \mathrm{kg}^{-1}$ fresh weight and celery

\begin{tabular}{|c|c|c|c|c|}
\hline \multicolumn{5}{|c|}{$\begin{array}{c}\text { TABLE-1 } \\
\text { NITRITE CONTENT ( } \mathrm{mg} \mathrm{kg}^{-1} \text { FRESH WEIGHT) OF VEGETABLES }\end{array}$} \\
\hline Category & Vegetable & Mean \pm SD & Min & Max \\
\hline \multirow{4}{*}{ Solanaceous vegetables } & Sweet pepper & $1.00 \pm 0.24 \mathrm{~cd}$ & 0.52 & 1.31 \\
\hline & Eggplant & $0.66 \pm 0.05 \mathrm{~d}$ & 0.58 & 0.75 \\
\hline & Hot pepper & $0.16 \pm 0.04 \mathrm{~d}$ & 0.09 & 0.24 \\
\hline & Tomato & $0.12 \pm 0.04 \mathrm{~d}$ & 0.04 & 0.19 \\
\hline \multirow{3}{*}{ Gourd vegetables } & Bitter gourd & $2.07 \pm 0.16 \mathrm{c}$ & 1.84 & 2.39 \\
\hline & Cucumber & $0.57 \pm 0.15 \mathrm{~d}$ & 0.35 & 0.85 \\
\hline & Towel gourd & $0.60 \pm 0.03 \mathrm{~d}$ & 0.54 & 0.63 \\
\hline \multirow{6}{*}{ Allium vegetables } & Old ginger & $4.93 \pm 0.11 b$ & 4.81 & 5.14 \\
\hline & Chinese chive & $0.70 \pm 0.17 \mathrm{~d}$ & 0.39 & 0.97 \\
\hline & Chinese onion & $0.54 \pm 0.39 \mathrm{~d}$ & 0.09 & 1.32 \\
\hline & Fresh ginger & $0.53 \pm 0.06 \mathrm{~d}$ & 0.42 & 0.64 \\
\hline & Garlic Scape & $0.48 \pm 0.08 \mathrm{~d}$ & 0.31 & 0.6 \\
\hline & Garlic & $0.47 \pm 0.18 \mathrm{~d}$ & 0.28 & 0.82 \\
\hline \multirow{2}{*}{ Tuber vegetables } & Potato & $1.36 \pm 0.14 \mathrm{~cd}$ & 1.09 & 1.53 \\
\hline & Sweet potato & $1.09 \pm 0.46 \mathrm{~cd}$ & 0.50 & 1.99 \\
\hline \multirow{2}{*}{ Root vegetables } & Carrot & $1.34 \pm 0.45 \mathrm{~cd}$ & 0.52 & 2.08 \\
\hline & White radish & $0.17 \pm 0.03 \mathrm{~d}$ & 0.13 & 0.22 \\
\hline \multirow{3}{*}{ Chinese cabbage group } & Cabbage & $1.47 \pm 0.32 \mathrm{~cd}$ & 0.82 & 1.84 \\
\hline & Chinese cabbage & $0.88 \pm 0.23 \mathrm{~cd}$ & 0.44 & 1.17 \\
\hline & Rape & $0.86 \pm 0.57 \mathrm{~cd}$ & 0.16 & 2 \\
\hline \multirow{4}{*}{ Green leafy vegetables } & Rorippa & $6.14 \pm 0.73 \mathrm{a}$ & 4.76 & 7.27 \\
\hline & Leaf lettuce & $0.57 \pm 0.26 \mathrm{~d}$ & 0.1 & 1.01 \\
\hline & Celery & $0.22 \pm 0.03 \mathrm{~d}$ & 0.17 & 0.29 \\
\hline & Iceberg lettuce & $0.32 \pm 0.12 \mathrm{~d}$ & 0.1 & 0.52 \\
\hline \multirow{2}{*}{ Leguminaceous vegetables } & Cowpea & $0.47 \pm 0.13 \mathrm{~d}$ & 0.23 & 0.68 \\
\hline & Kidney bean & $0.19 \pm 0.07 \mathrm{~d}$ & 0.04 & 0.29 \\
\hline Aquatic vegetables & Bamboo shoot & $1.48 \pm 0.25 \mathrm{~cd}$ & 1.21 & 1.98 \\
\hline Edible fungi & Pleurotus & $1.35 \pm 0.10 \mathrm{~cd}$ & 1.23 & 1.56 \\
\hline
\end{tabular}


had the lowest at $0.22 \mathrm{mg} \mathrm{kg}^{-1}$ fresh weight. Nitrate levels in rorippa were higher $(\mathrm{P}<0.05)$ than those in other vegetables, such as leaf lettuce, celery and iceberg lettuce, in the green leafy vegetable group. No significant differences were found between cowpea and kidney bean, in the leguminaceous group.

Vegetable consumption patterns: According to the vegetable consumption Survey, the 2.628 million people living in northeast Chongqing consume 426.7 thousand tons of vegetables per year, which is $440 \mathrm{~g}$ of tested vegetables per day. Solanaceous vegetables accounted for $18.23 \%$ of the total vegetables consumed, whereas gourd, allium and tuber vegetables accounted for 16.36, 14.68 and $10.35 \%$, respectively. In other categories of vegetables, each contributed less than $10 \%$ to the total vegetable consumption. Consumption data for different categories of vegetables is shown in Table-2.

\begin{tabular}{|c|c|c|}
\hline \multicolumn{3}{|c|}{$\begin{array}{c}\text { TABLE-2 } \\
\text { VEGETABLE CONSUMPTION PATTERNS } \\
\text { FOR PEOPLE LIVING IN THE STUDY AREA }\end{array}$} \\
\hline Vegetable & $\begin{array}{l}\text { Mean consumption } \\
\left(\mathrm{g} \mathrm{day}^{-1}\right)\end{array}$ & $\begin{array}{l}\text { Percentage } \\
(\%)\end{array}$ \\
\hline Solanaceous vegetables & 80.21 & 18.23 \\
\hline Gourd vegetables & 71.98 & 16.36 \\
\hline Allium vegetables & 64.59 & 14.68 \\
\hline Tuber vegetables & 45.54 & 10.35 \\
\hline Root vegetables & 33.92 & 7.71 \\
\hline Chinese cabbage group & 23.89 & 5.43 \\
\hline Green leafy vegetables & 39.82 & 9.05 \\
\hline Leguminaceous vegetable & 26.31 & 5.98 \\
\hline Aquatic vegetables & 6.56 & 1.49 \\
\hline Edible fungi & 0.57 & 0.13 \\
\hline Others & 46.60 & 10.59 \\
\hline
\end{tabular}

Dietary exposure to nitrites from vegetables: The nitrite content of each vegetable category is shown in Table-3. Vegetable groups in decreasing order of mean nitrate content are as follows: Green leafy vegetables $(1.81 \pm 0.77)>$ aquatic vegetables $(1.48 \pm 0.25)>$ edible fungi $(1.35 \pm 0.10)>$ allium vegetables $(1.28 \pm 0.40)>$ tuber vegetables $(1.22 \pm 0.22)>$ gourd vegetables $(1.08 \pm 0.26)>$ Chinese cabbage group (1.07 $\pm 0.22)>$ root vegetables $(0.75 \pm 0.33)>$ solanaceous vegetables $(0.48 \pm 0.12)>$ leguminaceous vegetables $(0.33 \pm$ 0.09). No significant differences were found among the groups.

Dietary exposure to nitrites from vegetables according to the mean consumption of vegetables for people living in the northeast areas of Chongqing. The dietary exposure to nitrite from vegetables was estimated to be $0.0066 \mathrm{mg} \mathrm{kg}^{-1}$ body weight day ${ }^{-1}$, which represents $90 \%$ of the whole vegetables consumption in northeast Chongqing. The estimated exposure to nitrite was well below the acceptable daily intake (ADI), which is $0.07 \mathrm{mg} \mathrm{kg}^{-1}$ body weight day ${ }^{-1}$ according to the Joint FAO/WHO expert committee on food additives. This assessment was in concordance with reports from previous studies $^{21,22}$.

\section{Conclusion}

This study provides the first estimation of exposure to nitrite from vegetables for the permanent resident population of cities experiencing migration from the three gorges project in northeast Chongqing, China. The results showed considerable significant variation in average levels of nitrite in various
TABLE-3

NITRITE CONTENT ( $\mathrm{mg} \mathrm{kg}^{-1}$ ) OF VEGETABLES (UNCOOKED) AVAILABLE IN MARKETS IN NORTHEAST CHONGQING

\begin{tabular}{|c|c|c|c|c|c|}
\hline Category & $\mathrm{N}$ & Mean \pm SD & Mini. & Max. & $\begin{array}{l}\text { Dietary exposure } \\
\left(\mathrm{mg} \mathrm{kg}^{-1} \text { body }\right. \\
\left.\text { weight day }{ }^{-1}\right)\end{array}$ \\
\hline $\begin{array}{l}\text { Solanaceous } \\
\text { vegetables }\end{array}$ & 120 & $0.48 \pm 0.12$ & 0.04 & 1.31 & 0.0006 \\
\hline Gourd vegetables & 90 & $1.08 \pm 0.26$ & 0.35 & 2.39 & 0.0013 \\
\hline Allium vegetables & 180 & $1.28 \pm 0.40$ & 0.09 & 5.14 & 0.0014 \\
\hline Tuber vegetables & 60 & $1.22 \pm 0.22$ & 0.50 & 1.99 & 0.0009 \\
\hline Root vegetables & 60 & $0.75 \pm 0.33$ & 0.13 & 2.08 & 0.0004 \\
\hline $\begin{array}{l}\text { Chinese cabbage } \\
\text { vegetables }\end{array}$ & 90 & $1.07 \pm 0.22$ & 0.16 & 2.00 & 0.0004 \\
\hline $\begin{array}{l}\text { Green leafy } \\
\text { vegetables }\end{array}$ & 120 & $1.81 \pm 0.77$ & 0.10 & 7.27 & 0.0012 \\
\hline $\begin{array}{l}\text { Leguminaceous } \\
\text { vegetables }\end{array}$ & 60 & $0.33 \pm 0.09$ & 0.04 & 0.68 & 0.0001 \\
\hline Aquatic vegetables & 30 & $1.48 \pm 0.25$ & 1.21 & 1.98 & 0.0002 \\
\hline Edible fungi & 30 & $1.35 \pm 0.10$ & 1.23 & 1.56 & 0.0000 \\
\hline Total & 840 & $1.10 \pm 0.15$ & 0.04 & 7.27 & 0.0066 \\
\hline
\end{tabular}

vegetables, ranging from $0.12 \mathrm{mg} \mathrm{kg}^{-1}$ fresh weight in tomato to $6.14 \mathrm{mg} \mathrm{kg}^{-1}$ fresh weight in rorippa.

Dietary exposure to nitrite from vegetables, estimated using the Northeast Chongqing population-based vegetable consumption Survey, 2005-2007, was well below the ADI. Consumption of vegetables is known to be very beneficial to our health. Lowering storage time has been suggested to reduce conversion of nitrate to nitrite in vegetables, as indicated by the significant difference between old ginger, with $4.93 \pm 0.11$ $\mathrm{mg} \mathrm{kg}^{-1}$ fresh weight and fresh ginger, with $0.53 \pm 0.06 \mathrm{mg}$ $\mathrm{kg}^{-1}$ fresh weight. The results of our study indicate that in northeast Chongqing, it is advisable to eat a wide variety of vegetables, rather than to focus on green leafy vegetables.

\section{ACKNOWLEDGEMENTS}

Project supported by National Natural Science Foundation of China (Grant No. 41301248), Scientific and Technological Research Program of Chongqing Municipal Education Commission (Grant No. KJ121108), Key Laboratory of Reservoir Aquatic Environment, Chongqing Institute of Green and Intelligent Technology, Chinese Academy of Science (Grant No. RAE2014BA01B) and Chongqing Municipal Key Laboratory of Institutions of Higher Education (Grant No. WEPKL2013MS-06).

\section{REFERENCES}

1. S.N. Bhupathiraju, N.M. Wedick, A. Pan, J.E. Manson, K.M. Rexrode, W.C. Willett, E.B. Rimm and F.B. Hu, Am. J. Clin. Nutr., 98, 1514 (2013).

2. P. Boffetta, E. Couto, J. Wichmann, P. Ferrari, D. Trichopoulos, H.B. Bueno-de-Mesquita, F.J.B. van Duijnhoven, F.L. Buchner, T. Key, H. Boeing, U. Nothlings, J. Linseisen, C.A. Gonzalez, K. Overvad, M.R.S. Nielsen, A. Tjonneland, A. Olsen, F. Clavel-Chapelon, M.C. BoutronRuault, S. Morois, P. Lagiou, A. Naska, V. Benetou, R. Kaaks, S. Rohrmann, S. Panico, S. Sieri, P. Vineis, D. Palli, C.H. van Gils, P.H. Peeters, E. Lund, M. Brustad, D. Engeset, J.M. Huerta, L. Rodriguez, M.J. Sanchez, M. Dorronsoro, A. Barricarte, G. Hallmans, I. Johansson, J. Manjer, E. Sonestedt, N.E. Allen, S. Bingham, K.T. Khaw, N. Slimani, M. Jenab, T. Mouw, T. Norat, E. Riboli and A. Trichopoulou, J. Natl. Cancer Inst., 102, 529 (2010).

3. T. Key, Br. J. Cancer, 104, 6 (2011). 
4. W.-L. Hsu, W.-H. Pan, Y.-C. Chien, K.J. Yu, Y.-J. Cheng, J.-Y. Chen, M.-Y. Liu, M.-M. Hsu, P.-J. Lou, I.-H. Chen, C.-S. Yang, A. Hildesheim and C.-J. Chen, PLoS ONE, 7, e41779 (2012).

5. S.E. Berry, U.Z. Mulla, P.J. Chowienczyk and T.A. Sanders, Br. J. Nutr., 104, 1839 (2010).

6. L. Denis, M. Morton and K. Griffiths, Eur. Urol., 35, 377 (1999).

7. S.E. Chiuve, T.T. Fung, E.B. Rimm, F.B. Hu, M.L. McCullough, M. Wang, M.J. Stampfer and W.C. Willett, J. Nutr., 142, 1009 (2012).

8. H. Boeing, A. Bechthold, A. Bub, S. Ellinger, D. Haller, A. Kroke, E. Leschik-Bonnet, M.J. Müller, H. Oberritter, M. Schulze, P. Stehle and B. Watzl, Eur. J. Nutr., 51, 637 (2012).

9. V. Butterweck, L. Semlin, B. Feistel, I. Pischel, K. Bauer and E.J. Verspohl, Phytother. Res., 25, 370 (2011).

10. Y.H. Loh, P. Jakszyn, R.N. Luben, A.A. Mulligan, P.N. Mitrou and K.T. Khaw, Am. J. Clin. Nutr., 93, 1053 (2011).

11. R. Dubrow, A.S. Darefsky, Y. Park, S.T. Mayne, S.C. Moore, B. Kilfoy, A.J. Cross, R. Sinha, A.R. Hollenbeck, A. Schatzkin and M.H. Ward, Cancer Epidemiol. Biomarkers Prev., 19, 1709 (2010).

12. G.-I. Lee, H.-M. Lee and C.-H. Lee, Food Contr., 24, 1 (2012).

13. A. Milkowski, H.K. Garg, J.R. Coughlin and N.S. Bryan, Nitric Oxide, 22, $110(2010)$
14. K. Larsson, P.O. Darnerud, N.-G. Ilbäck and L. Merino, Food Addit. Contam., 28, 659 (2011).

15. M.P.V. Azanza and A.S. Rustia, Food Contr., 15, 385 (2004).

16. S.-M. Shim, S.H. Seo, Y. Lee, G.-I. Moon, M.-S. Kim and J.-H. Park, Food Contr., 22, 1054 (2011).

17. J. Lin, C. Fu, X. Zhang, K. Xie and Z. Yu, Biol. Trace Elem. Res., 145, 268 (2012).

18. L. Dongmei, L. Heping, T. Na, D. Jun and Y. Peng, Chinese Agric. Sci. Bull., 6, 59 (2011).

19. B.-J. Fu, B.-F. Wu, Y.-H. Lü, Z.-H. Xu, J.-H. Cao, Dong Niu, G.-S. Yang and Y.-M. Zhou, Prog. Phys. Geogr., 34, 741 (2010).

20. WHO, Nitrate and Nitrite-intake Assessment. In: Safety Evaluation of Certain Food Additives, Food Additives Series 50, Geneva: WHO, (2003); Available from: http://www.inchem.org/documents/jecfa/ jecmono/v50je07.htm

21. A. Shahlaei, N.A. Ansari and F.S. Dehkordie, Asian J. Plant Sci., 6, 1197 (2007).

22. M. Correia, Â. Barroso, M.F. Barroso, D. Soares, M. Oliveira and C. Delerue-Matos, Food Chem., 120, 960 (2010). 